\title{
RÉPLICA: COMPARAÇÃO IMPOSSÍVEL
}

\author{
Por Luiz Carlos Bresser-Pereira \\ Professor da FGV-EESP \\ E-mail: bresserpereira@uol.com.br
}

Imagine-se que alguém comparasse uma colher com uma maçã, e manifestasse sua clara preferência pela segunda. A perplexidade do interlocutor seria enorme. Pois bem, fiquei quase tão perplexo quando li esse artigo comparando a administração pública gerencial com a "gestão social". Conheço bem o que é a gestão pública moderna, ou a administração pública gerencial, já que me envolvi profundamente no desenvolvimento de uma teoria democrática e participativa para ela, e fui o responsável inicial pela realização da Reforma da Gestão Pública de 1995-1998. Trata-se de uma nova forma de organizar e administrar o Estado, que se opõe à administração pública burocrática, a qual pretende substituir. Não se trata de uma forma de governar, de escolher entre um regime democrático meramente liberal ou um regime democrático participativo, mas de saber como gerir o aparelho do Estado e os serviços sociais e científicos que o Estado decide financiar. Já o conceito de gestão social, na forma como é apresentado no artigo, não é uma forma de organizar e administrar o aparelho do Estado, mas um aspecto da democracia participativa. Segundo o artigo,

[...] um aparelho do Estado com características participativas deve permitir a infiltração do complexo tecido mobilizatório, garantindo a legitimidade das demandas populares. Para isso é preciso criar arranjos institucionais que organizem a participação nas diferentes esferas governamentais que sejam dinâmicas 0 suficiente para absorver as tendências cambiantes inerentes à democracia ( $p .44)$.

0 exemplo oferecido de gestão social é o Orçamento Participativo, que é uma experiência bem-sucedida de democracia participativa em âmbito local. 0 artigo está comparando, portanto, duas coisas muito diferentes: um tipo de administração pública e uma forma de governo ou de regime político.

De acordo com a classificação histórica que desenvolvi de democracias, tivemos inicialmente, nos países mais avançados, na primeira metade do século XX, uma democracia de elites ou schumpeteriana; na segunda metade, uma democracia de opinião pública ou social; e estamos começando a assistir à transição para uma forma superior de democracia: a participativa ou republicana. A administração pública gerencial, que tenho chamado também de gestão pública, pressupõe a existência de um regime democrático, já que seu princípio mais geral é dar mais autonomia aos gestores públicos em troca de um responsabilização maior da sua parte, que é possível apenas numa democracia. N ão define, porém, qual é o tipo de democracia, se de elites, de opinião publica, ou participativa.

Pessoalmente, tenho uma declarada preferência por uma democracia participativa e republicana, e, por isso, o modelo de administração gerencial que desenvolvi em meus trabalhos tem um claro sentido participativo. 0 mesmo se expressa, fundamental mente, em uma das três formas de controle específicas da gestão pública. Enquanto a administração pública burocrática controla por regulamentos detalhados, supervisão e auditoria, a gestão pública reduz esses controles e aumenta o papel da administração por resultados, da concorrência administrada por excelência e do controle ou responsabilização social.

É por meio desta última forma de controle que a administração pública gerencial do tipo que defendo e que procurei implantar no Brasil - há outros tipos, inclusi- 
ve 0 estritamente neoliberal como aquele tentado com maus resultados na N ova Zelândia, durante al gum tempo - estabel ece uma clara ponte com a democracia participativa. Instituições como os conselhos gestores, e como o Orçamento Participativo, são formas de participação e controle social que defendi e defendo como essenciais para uma boa gestão pública.

Se os autores querem chamar esse tipo de gestão pública de "gestão social", não tenho objeções. Haveria assim uma "administração pública gerencial social". E assim seria possível distingui-la não apenas da administração pública burocrática, mas tam- bém de versões mais liberais e autoritárias de administração pública gerencial. 0 que não podem, porém, é comparar modelo de administração pública com tipo de regime político. Como também não podem colocar todas as versões de administração pública gerencial numa mesma categoria e associá-las às "estratégias neoliberais", ao "Consenso de Washington". Sempre fui um crítico de ideologias conservadoras desse tipo, e nos trabalhos que escrevi sobre a administração pública gerencial e nas Reforma da Gestão Pública de 1995-1998, à qual me dediquei, rejeitei-as sempre. 